SHS Web of Conferences 23, 02003 (2016)

DOI: $10.1051 /$ shsconf/ 20162302003

(C) Owned by the authors, published by EDP Sciences, 2016

\title{
ADOPTING ZERO INTEREST FINANCING MODEL (ZIFM) IN ISLAMIC MICROFINANCE INSTITUTIONS: THE CASE OF SHARIAH PEOPLE CREDIT BANK (BPRS), INDONESIA
}

\author{
MOHAMED ASMY BIN MOHD THAS THAKER and \\ HASSANUDIN BIN MOHD THAS THAKER \\ Department of Economics, \\ Kulliyyah of Economics and Management Sciences, \\ International Islamic University Malaysia (IIUM) \\ e-mail: asmykin83@yahoo.co.uk \\ Department of Business, HELP University, \\ BZ-2, Pusat Bandar Damansara (Main Block), 50490, \\ Kuala Lumpur, Malaysia
}

\begin{abstract}
Microfinance has emerged as an important instrument to alleviate poverty in many countries including in developing countries. Despite being able to demonstrate successes in the activity, conventional microfinance is not without controversy. The findings from the existing studies revealed that conventional microfinance is less effective, fail to reach the poorest people and generally have a limited effect on income. In addition, conventional microfinance also has highly criticized for charging excessive interest rates and fees to the poor entrepreneur. In some Muslim countries, conventional microfinance has always been rejected, due to its noncompliance with the Islamic principles, particularly on the issue related to interest or riba. Islamic microfinance evolved and reckoned as an alternative to its counterpart. However, the outreach of Islamic microfinance is very limited where only there is very few Islamic microfinance institutions and Islamic banks involved in microfinance activity. Also, Islamic microfinance is having an issue of convergence of activity with the conventional practices. Thus, this paper aims to propose to adopt Zero Interest Financing Model (ZIFM) for Islamic microfinance institutions. This study focuses on the case of Indonesian Islamic microfinance institution namely Shariah People Credit Bank (BPRS) by observing their experience and some emerging issues. The proposed model is expected to address an emerging issue in Islamic microfinance institutions.
\end{abstract}

Keywords: Islamic Microfinance, Issues, Zero Interest Financing Model (ZIFM) 


\section{INTRODUCTION}

According to Otero (1999), micro finance is defined as the provision of financial services to low-income poor and very poor self-employed people. Also financial services according to Ledgerwood (1999) generally include savings, credit and also include other financial services such as insurance and payment services. Therefore, microfinance involves the provision of financial services such as savings, loans and insurance to poor people who are unable to obtain such services from the formal financial sector.

According to the UNCDF (2004), there are approximately 10,000 MFIs in the world with more than 30 million clients. Furthermore, according to the Microcredit Summit Campaign Report (Microcredit Summit, 2004) as of December 31st 2003, so far 2,931 microcredit institutions have claimed that their clients reached to $80,868,343$ clients.

The main characteristics of a microfinance institution are such that, (i) it is a substitute for formal financial institutions; (ii) generally requires no collateral; (iii) have simple procedures and less documentation; (iv) easy and flexible repayment schemes; (v) financial assistance of members of group in case of emergency; (vi) most deprived segments of population are efficiently targeted; and, (vii) lastly is groups interaction. Basically, half of these microfinance institutions, however, have nothing more than subjective stories about the impact of MF on poverty.

According to UNCDF (2004), microfinance plays three key roles in development. It helps poor households to meet basic needs and protects against risks, improving in household economic welfare, helps to empower women by supporting women's economic participation and so promotes gender equity. It is also supported by various authors that microfinance brings positive impacts to the people particularly poor people. It is also supported by earlier study by Otero (1999). Otero (1999) states that microfinance creates access to productive capital for the poor to uplift human capital of the poor. It is done through education and training, and also through local organisation building. It helps to poor people to move out of poverty. By providing material capital to a poor person, their sense of dignity is strengthened and this can help to empower the person to participate in the economy and society.

Meanwhile, Littlefield \& Rosenberg (2004) claimed that microfinance institutions have emerged when the poor are generally excluded from the financial services sector of the economy. Microfinance institutions can become integral part of the formal financial system of a country to address this gap in the market in a financially sustainable manner. By this, the poor can easily access to fund and capital. Also it also assists micro finance to increase the 
number of poor people they can reach (Otero, 1999). More recently, several authors also have commented on the role of microfinance in achieving the Millennium Development Goals (Littlefield et.al, 2003; Simanowitz \& Brody, 2004). Simanowitz \& Brody (2004) stated that microfinance has played a role in eradicating poverty, promoting education, improving health and empowering women. It shows that microfinance can deliver social benefits on an ongoing, permanent basis and on a large scale. It also helps to achieve Millennium Development Goals of every nation including developed and developing countries.

However, despite being able to demonstrate successes in the activity, conventional microfinance is not without controversy. Many studies have examined empirically to test the effectiveness of microfinance (Hulme \& Mosley, 1996; Wright, 2000). The findings revealed microfinance is not fully reaching its effectiveness and impacts. For example, Hulme \& Mosley (1996), while acknowledging the role microfinance can have in helping to reduce poverty, they concluded from their research that most contemporary microfinance schemes are less effective as expected. They stated that microfinance is not a remedy for povertyalleviation instead of making the poorest people to become worse-off.

It is also supported by Wright (2000) where he stated that microfinance projects fail to reach the poorest people and generally microfinance have a limited effect on income. On the other hand, conventional microfinance institutions also have often been highly criticized for charging excessive interest rates and fees to the poor (IRTI, 2007). It occurs due to the fact that microfinance institutions have to bear high transaction costs that including the provision of services such as monitoring, advice and health insurance.

Furthermore, conventional microfinance has shown inadequate interest in religious and cultural sensitivities (Muhammad, 2012). In some Muslim countries particularly, conventional microfinance has always been rejected, due to its non-compliance with the Islamic principles, particularly on the issue related to interest or riba (Muhammad, 2012).

Thus, as an alternative to conventional microfinance, Islamic microfinance evolved to substitute conventional microfinance. Recently, there are few efforts by Islamic microfinance institutions initiatives are emerging in the microfinance industry, providing interest-free Islamic products mostly in Muslim country such as in Indonesia, Bangladesh, Sudan and Pakistan. They operating by offering different products and serve as an alternative to its counterpart.

However, the outreach of Islamic microfinance institutions is very limited where only there are very only few Islamic microfinance institutions and Islamic banks involved in microfinance (ABAC Malaysia, 2008). Apart from that, Islamic microfinance institutions 
also facing its own issue where the existing practices of Islamic microfinance institutions tend to converge with the conventional practices (Muhammad, 2012). For example, the financing modes being used by the Islamic microfinance institutions are mostly debt-based, which have similarity to the interest-based conventional modes (Muhammad, 2012). Some operations of Islamic microfinance institutions in some Muslim countries tend to be costly due to the dominant of Murabahah practices or administrative charges that are tantamount to riba (Hassan, 2010; Muhammad, 2012).

Thus, this paper observes that there is a need to come out with a viable model that can meet the need of microfinance clients particularly Muslim clients. Considering this factor, this paper aims to propose Zero Interest Financing Model (ZIFM) for Islamic microfinance institutions. This study will focus on the case of Indonesian Islamic microfinance institution namely Shariah People Credit Bank (BPRS) by observing their experience and some emerging issues. Later, this study will provide the framework and mechanisms of Zero Interest Financing Model and its implication to Islamic microfinance institutions in general. The last section will provide some conclusion and recommendations.

\section{OVERVIEW OF ISLAMIC MICROFINANCE INSTITUTION IN INDONESIA}

In this section, it aims to explore the emerging Islamic microfinance sector in Indonesia particularly Shariah People Credit Bank (BPRS). This institution become among the main players of Islamic microfinance institution in Indonesia. It will briefly look at how they have evolved and development.

\section{Shariah People Credit Bank (BPRS)}

In 1990, Majlis Ulama Indonesia (MUI) or the Indonesian National Council of Islamic Scholars began a study to prepare the establishment of an interest-free banking system (Rulindo, 2012). The study was a big step as it supported the establishment of People Credit Bank (BPR) based on Shariah principles. These institutions were known as Bank Perkreditan Rakyat Shariah (BPRS) or Islamic Rural Bank. Of 90 BPRS ever licensed between 1991 and June 2004, 86 are still active (Riwajanti \& Asutay, 2013).

BPRS has defined as a bank conducting banking/business activities based on Shariah principles according to Act No 7/1992 on Banking as revised by Act No 10/1998 (Riwajanti $\&$ Asutay, 2013). BPRS engaged with the Shariah principle and offered financial instruments based on the profit-loss-sharing (PLS) principle (Mudharabah), equity financing capital through Musharakah, based on the selling principle (Murabaha), or financing capital goods 
on the basis of a pure lease option (Ijarah) or with option of removal of ownership of the leased items from the bank by another party (Ijara Wa Istisna) (Riwajanti \& Asutay, 2013).

BPRSs are privately owned and regulated and supervised by Bank Indonesia. They are licensed to offer banking services (loans and savings facilities, but no payments services) in a district area only. BPRSs are more socially oriented. Their mission statement calls for supporting the community and, in particular, small traders and micro entrepreneurs (Rulindo, 2012; Riwajanti \& Asutay, 2013).

The growth pattern of BPRS was quite different. During the initial period of gradual growth until 1996, the number of BPRS reached to 71 and in 1998 and 2003, their number almost stagnated, 78 and 84, respectively as shown in Table 1. During the four-year period, 1999-2003, the number of BPRS grew by only 8\% from 78 to 84 . However, in 2007 and 2008, there was re-expansion of BPRS with the numbers jumped to 114 and 128, respectively.

Table 1: The Evolution Of BPRS

\begin{tabular}{|c|c|c|c|}
\hline No & Phase & Period & No of BPRS \\
\hline 1 & Gradual Expansion & $1991-1996$ & 71 \\
\hline 2 & Slow Down Of Expansion & Up to 1998 & 84 \\
\hline 3 & Stagnation & Up to 2003 & 114 \\
\hline 4 & Re-Expansion & Up to 2007 & 128 \\
\hline
\end{tabular}

Source: Seibel (2008)

The development of BPRS gets full support from Bank Indonesia. The support from Bank Indonesia can be seen from the size of BPRS, value of assets and the scope of operation. For instance, the number of BPRS offices has also increased three times during 2005-2010 from 92 to 155 as shown in Table 2. It is also followed with the increased of the number of branch offices. In 2012, there were about 390 branch offices of BPRs operated in Indonesia. The growth of BPRS offices is even higher than the growth of BPR offices itself.

Table 2: The Development of BPRS

\begin{tabular}{|c|c|c|c|c|c|}
\hline Items & $\mathbf{2 0 0 0}$ & $\mathbf{2 0 0 5}$ & $\mathbf{2 0 1 0}$ & $\mathbf{2 0 1 1}$ & $\mathbf{2 0 1 2}$ \\
\hline BPRS & 78 & 92 & 150 & 155 & 155 \\
\hline Branch Offices & & & 286 & 364 & 389 \\
\hline
\end{tabular}

Source: Rulindo (2012), Seibel (2008), Riwajanti \& Asutay (2013) 
A similar pattern is also happening in financial position of BPRS. It is shown in Table 3 where the financial indicators such as asset, depositors' funds (savings), financing and capital indicated that BPRS enjoy better performance in terms of growth.

Table 3: Financial Position of BPRS

\begin{tabular}{|c|c|c|c|c|c|c|}
\hline Item (in billion Rupiah) & $\mathbf{2 0 0 5}$ & $\mathbf{2 0 0 6}$ & $\mathbf{2 0 0 7}$ & $\mathbf{2 0 0 8}$ & $\mathbf{2 0 0 9}$ & $\mathbf{2 0 1 0}$ \\
\hline Asset & 585 & 896 & 1215 & 1693 & 2123 & 2739 \\
\hline Depositors' fund & 341 & 521 & 718 & 976 & 1251 & 1604 \\
\hline Financing & 417 & 615 & 891 & 1257 & 1587 & 2060 \\
\hline Paid in Capital & 118 & 151 & 177 & 222 & 751 & 806 \\
\hline Current Earning (profit/loss) & 16 & 21 & 27 & 30 & 55 & 70 \\
\hline
\end{tabular}

Source: Rulindo (2012)

Table 4 illustrates the other financial indicators of BPRS such as Financing to Deposit Ratio, Non Performance Financing, Return on Asset (ROA) and Return on Equity (ROE). Overall, BPRS's carry out their role as financial intermediary with better performance and it is shown by the Financing to Deposit Ratio. The total amounts of financing given by BPRS even exceed their total deposit. This is means BPRS also use a part of their capital to finance their clients. The Return on Asset (ROA) of BPRS is also higher and followed with The Return on Equity (ROE). It indicates that BPRS are able to accumulate more savings.

Table 4: Other Financial Indicators of BPRS

\begin{tabular}{|c|c|c|c|c|c|c|}
\hline Item (in billion Rupiah) & $\mathbf{2 0 0 5}$ & $\mathbf{2 0 0 6}$ & $\mathbf{2 0 0 7}$ & $\mathbf{2 0 0 8}$ & $\mathbf{2 0 0 9}$ & $\mathbf{2 0 1 0}$ \\
\hline Financing to Deposit Ratio & 122.4 & 118.1 & 124.08 & 128.78 & 126.89 & 128.47 \\
\hline Non Performance Financing & 10.9 & 8.3 & 8.11 & 8.38 & 7.03 & 6.5 \\
\hline Return on Asset (ROA) & 4.05 & 3.79 & 3.21 & 2.76 & 5 & 3.49 \\
\hline Return on Equity (ROE) & 11.21 & 9.82 & 11.21 & 14.77 & 21.55 & 14.29 \\
\hline
\end{tabular}

Source: Rulindo (2012)

\section{ISSUES OF ISLAMIC MICROFINANCE INSTITUTIONS}

Despite the remarkable achievements of Islamic microfinance institutions in Indonesia, there remained several issues that confronted the growth of Islamic microfinance institutions and need to be improved to ensure its continuous development and successful implementation. These issues are very common in many Islamic microfinance institutions. Among the issues that need to be addressed are: (i) lack of funds/capital (ii) question of 
authenticity (iii) less number of Mudharabah and Musharakah financing contracts and (iv) high transaction costs.

\section{Lack of Funds/Capital}

Most of the surveyed Islamic microfinance institutions argue that expansion of their activities is hampered by lack of funds. Lack of fund is among the perpetual problems confronting the Islamic microfinance players. Lack of capital leads Islamic microfinance institutions to have difficulty in scaling up. Finally, they are neither grow out of retained earnings nor can they raise capital in financial markets (Gibbons \& Meehan, 2004).

Islamic microfinance institutions cannot attract deposits as donors and effectively accumulate savings from members and communities (Ahmed, 2003). Islamic microfinance institutions also failed to attract commercial banks to provide them with the fund. Furthermore, Islamic microfinance institutions have not yet tapped the funds from Islamic institutional sources of Zakat, Charity, and Waqf (Ahmed, 2003).

According to Ahmed (2003), there are certain problems in obtaining funds from external sources by Islamic microfinance institutions. First, although some funds are provided by government agencies and relevant agencies, they impose certain terms and conditions. These terms and conditions are opposing to Islamic principles and limit the flexibility Islamic microfinance institutions' operation (Ahmed, 2003). For example, the funds are given on interest-based and the microfinance institutions are required to recover a certain fixed rate of return of their investments (Ahmed, 2003). As a result, funds from these sources cannot be employed in micro financing using certain Islamic modes of financing (like Mudarabah and Musharakah).

Second, the Islamic educational content of Islamic microfinance institutions also discourages some external sources from providing funding to Islamic microfinance institutions (Ahmed, 2003). Since, Islamic microfinance institutions established based on Islamic principles, thus some external financiers is reluctant to provide fund to Islamic microfinance institutions.

\section{Question of Authenticity}

According to Karim et.al (2008), question of authenticity is related to the basic principle of Islamic finance which is to eliminate Riba, Gharar and Maysir. The Islamic financial services institutions including Islamic microfinance institutions need to fulfil these three basic principles in their operation. 
However, in the current practice of Islamic microfinance institutions, Islamic microfinance institutions find a way to imitate and provide products and services just like conventional banks. Islamic microfinance institutions resemble conventional microfinance activity by focusing on the debt financing instruments particularly Murabahah. Murabahah become the most popular and widely used contract in Islamic microfinance institutions. In many Muslim countries including in Indonesia, the market share of Murabahah financing reaches more than 90 percent of total financing (Rulindo, 2012).

The critics of Murabahah product is that the pricing is too closely parallels (or even sometimes exceeds) to the pricing of conventional products (Rahman \& Dean, 2013; Muhammad, 2012). For example, some Murabahah seem to cover-up interest as a cost markup or administration fee. Furthermore, Murabahah also tends to be less flexible, and does not allow borrowers to get cash they need to pay other expenses, such as utilities (Rahman \& Dean, 2013). All the issues that are arising pertaining to Murabahah contract illustrate the problem of authenticity in current Islamic microfinance practices.

\section{Limited Number of Mudharabah and Musharakah Financing}

In many cases, the number of Mudharabah and Musharakah financing offered by Islamic microfinance institutions is far below those in Murabahah financing. According to Rosly (2005), among the reasons that Islamic financial service institutions including the Islamic microfinance institutions offering less number of Mudharabah and Musharakah contracts are due to the existence of asymmetric information, moral hazard and adverse selection (Rulindo, 2012).

For the asymmetric information, since there is a possibility by the entrepreneurs to not disclose complete information about their business, it creates uncomfortable position of the Islamic microfinance institutions if they offer Mudharabah and Musharakah financing. The Islamic microfinance institutions need to face high risk in terms of losses caused by entrepreneurs.

Another factor is that related to adverse selection. According to Rosly (2005), adverse selection happens when borrowers with undesirable characteristics are chosen to receive financing. Since in many cases, there is lack of historical financial data by micro entrepreneurs, it leads Islamic microfinance institutions to be uncertain when selecting good clients (Saeed et al., 2009). For established Islamic microfinance institutions, they are not having problem since they can extend financing to clients with good performance. However, for the newly established Islamic microfinance institutions, they need to rely upon available 
information and it can cause them to choose borrowers with undesirable characteristics (Rulindo, 2012).

Since in Mudharabah contract the entrepreneurs are not liable for bearing any losses (unless due to his/her negligence), it can create moral hazard (Rulindo, 2012). The moral hazard can occur where the entrepreneurs who are also the clients of Islamic microfinance institutions equipped with low education and less experience in business, unable to plan for the future of their business (Rulindo, 2012). It may bring harm to Islamic microfinance institutions and it is also not be profitable for the Islamic microfinance institutions under these circumstances.

\section{High Transaction Costs}

Chowdhury (2006) mentioned that in Islamic microfinance institutions, the debt based financing dominated in their activity since there is too much uncertainty in profit/loss sharing models for Islamic microfinance institutions. This uncertainty leads to higher costs. Islamic microfinance institutions also cannot away from experiencing high transaction costs due to asymmetric information problems (Rahman \& Dean, 2013). These costs are basically related to monitoring and searching costs and also the cost of enforcement. Sometimes, microfinance institutions including Islamic microfinance institutions are related to small amount of financing/loan, but such small loans are very expensive because of high overhead costs.

From the above discussion, it shows that although there is growth in Islamic microfinance institutions in Indonesia in particular, they are facing couple of constraints that limit their expansion. These issues are continuously affected and very common in almost all existing Islamic microfinance institutions. Given these limitations that affected Islamic microfinance institutions continuously, we propose to adopt a viable model that able to provide a better avenue for Islamic microfinance institutions to grow and help the poor. In this paper, we propose to adopt Zero Interest Financing Model (ZIFM) within the context of Islamic microfinance institutions. In the next section, it will critically look at the some of the practices of ZIFM in conventional micro finance and propose the ZIFM within Islamic microfinance institutions.

\section{PRACTICE OF ZERO INTEREST FINANCING MODEL (ZIFM) IN OTHER COUNTRIES}

In this section, this paper looks at the existing implementation of ZIFM in other countries. Although ZIFM has been implemented in other countries, ZIFM is practiced based 
on conventional point of view. This paper explores ZIFM that are currently practised and they are known as Zero Interest Microfinance at Bauer (ZiMB) and Jerusalem Interest-Free Microfinance Fund (JIMF).

\section{Zero Interest Microfinance Bauer (ZiMB)}

Generally, the members of ZiMB comprised of young professionals from diverse ethnic backgrounds, cultures, and career aspirations. By creating social business projects, the members of ZiMB aim to do well in creating a profit to sustain the mission of ZiMB.

The mission statement of ZiMB is to increase social awareness and social responsibility. The objectives of ZiMB are to identify Non-Government Organizations (NGOs) that aim to integrate a microfinance component within their existing operations. By forming partnership between ZiMB and NGO, it will increase the effectiveness of the NGO by providing direct and reliable loans at zero interest to its clients. It also helps ZiMB to promote the ideas of global citizenship and perhaps inspire the next generation of social entrepreneurs.

The ZiMB strategy is to create a complementary partnership between the NGO in order to improve social responsibility. ZiMB provides loans at a $0 \%$ interest rate to qualifying borrowers who wish to use the loan in improving their economic condition and to create a better life for themselves and their family. The range of the loan depends on the needs of the borrower.

Among the uniqueness of $\mathrm{ZiMB}$ is that ZiMB will be responsible for recruiting lenders and maintaining an online lending platform. Later, ZiMB leaves NGO to do what it does best-form relationships with the people they are serving. Such relationships will facilitate loan repayment rates in the long run, further ensuring the success of the program.

Most of the beneficiaries of ZiMB are any client of the NGO who requires a loan for business start-up, education, investment, or community empowerment. The borrower is required to undergo a loan assessment process which determined by the NGO. The loan assessment includes income, capacity to repay, business plan, and any other factor that would influence the decision.

The roles of ZiMB are (i) to identify and recruit lenders and donations. Members of ZiMB collaborate to raise funds through networking, fundraising, corporate sponsorship, and social business that will be used for microfinance, (ii) to create and maintain an online lending platform. This platform brings lenders and borrowers together in an efficient and reliable manner. Through online platform, it contains information about the borrowers such 
as name and biography as well as a picture. It reflects a higher level of transparency and accountability to the lenders, and (iii) to involves a formal application and on-site visit to the NGO during the field-partner selection process. After selected, the NGO is required to present regular financial statements, reports, and feedback on the effectiveness of the microfinance project. At least once a year, members of ZiMB participate in an on-site visit with partnering NGOs. It will help to assess the impact of the loans and decide whether or not to renew and continue on with the microfinance partnership with the NGO.

In terms of the accountability of ZiMB, if there is a borrower defaults on any portion on their loan, the delinquency costs will be equally shared by ZiMB and NGO. For example, if a borrower fails to repay the full amount of $\$ 100$ and instead only pays $\$ 50, \mathrm{ZiMB}$ and NGO will each be responsible for $\$ 25$. By this way, the lenders can feel that their contribution to the program is safe, which will attract further contributions and more lenders. The borrower is required to go through a loan assessment process which is determined by the partner in the field. Through this way, it provides accountability and reduces delinquency costs.

ZiMB's long-term goal is to incorporate a successful microfinance project that empower the poor and disadvantage youth in many parts of the world. The microfinance project will benefit the borrower in terms of financial independence, attain financial stability, and bring a positive impact.

\section{The Jerusalem Interest-free Microfinance Fund (JIMF)}

The Jerusalem Interest-free Microfinance Fund (JIMF) was set up in 2008 by Jewish and Muslim Londoners to help the poor communities in Jerusalem. It is to help them to establish and to grow their own businesses by providing microfinance and technical assistance. The Jerusalem Interest-Free Micro-Finance Fund Limited (JIMF) is a UK charity set up for the relief of financial hardship amongst people in poor communities in Jerusalem by enabling them to establish and to grow their own businesses, through the provision of microfinance and technical assistance.

The JIMF objectives are (i) to alleviate of poverty, (ii) to build foundations of community cohesion and peace by increasing the economic and life chances of Muslims, Jews and Christians within the City of Jerusalem, (iii) to financially support without charge of interest to entrepreneurs with sound business propositions but limited funding to start up a business or to sustain or expand an existing business, (iv) to provide advice, information and 
financial support to those seeking business education or training, and (v) to coordinate the efforts with other micro-finance organisations providing funds in and around Jerusalem.

The Jerusalem Interest-free Microfinance Fund targets to help entrepreneurs and small businesses in Jerusalem, especially in the Arab and Charedi population segments. JIMF funding is compliant with both Shariah and Halacha. By avoiding the taking of interest, the fund satisfies the religious needs of both groups. To achieve the economic and social purpose of JIMF, it is essential to keep loan defaults at a very low level (less than five per cent has been achieved elsewhere) through provision of:

I. Pre-loan and post-loan training

II. Rigorous screening of business proposals

III. The establishment of credible but culturally sensitive enforcement mechanisms

JIMF has been running two pilot programmes during 2009 and 2010. During the pilots more than 55 women have received intensive training and more than 30 women have or will receive interest-free loans to help them launch new businesses or expand existing ones. The pilots are including the businesses such as nurseries, graphic design, apparel, educational workshops, pastry businesses, jewellers and beauty therapy. The average loan size is US $\$ 5,000$. All participants receive pre-loan and post-loan training, coupled with follow-up meetings.

This is among the advantage of JIMF's program as this helps to upgrade their clients' business and soft skills, boosts their confidence and ensures close support at the critical stages of the business after the disbursement of the loan. Typically, a programme targeting a group of 15 women will include:

- 56 hours of group training workshops.

- 5 hours of pre-loan one-to-one mentoring.

- Direct support in writing a business plan.

- 10 hours of post-loan one-to-one mentoring.

- An interest-free loan to qualifying participants.

Training is provided to the groups of Arab and Charedi women by the Freelance Group, an East Jerusalem specialist NGO, and by the Jerusalem Business Development Centre, MATI, a foundation supporting Jerusalem SMEs. These organisations work closely together and in collaboration with JIMF. The findings revealed that there were (i) new businesses launched and existing businesses expanded; and (ii) the women who led these businesses have been better able to provide for their families. 


\section{PROPOSED ZERO INTEREST FINANCING MODEL (ZIFM) FOR ISLAMIC MICROFINANCE INSTITUTIONS}

From the example of practice of ZIFM in other countries, it is claimed that the ZIFM can be used to support microfinance institutions. Due to this initiative, this paper proposes to adopt the use of ZIFM within the context of Islamic microfinance institutions particularly in Indonesia. ZIFM also can be applied to other Muslim countries.

This model is proposed with the aim to be as an alternative option for the microfinance institutions and clients. This proposed model is a kind of collaborative venture between the parties involved. The most important components of this model are the Islamic microfinance institutions and its client. The only difference that differentiates ZIFM from conventional and Islamic point of view is that under the proposed ZIFM for Islamic microfinance institutions, there is an existence of Tabarruq Capital Fund (TCF) or known as Donation to Capital Fund. The model is presented in Figure 1.

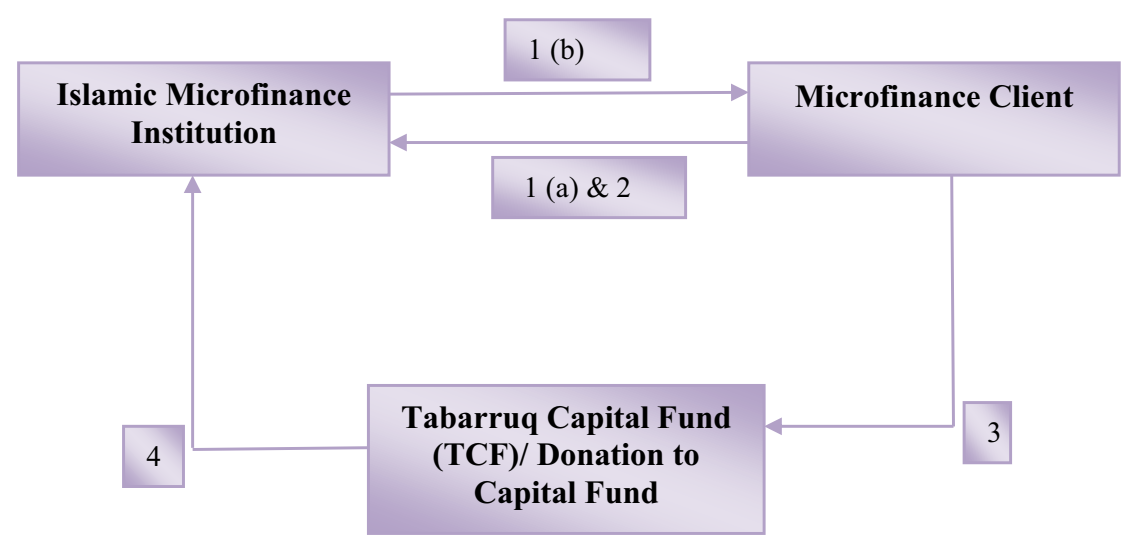

Figure 1: Conceptual Framework Of ZIFM For Islamic Microfinance Institution

Modus operandi of ZIFM for Islamic microfinance institutions

- At the initial point (1a), the microfinance client will approach Islamic microfinance institution to apply/get funding.

- Islamic microfinance institution will provide financing facility to the microfinance client (1b) without charging any additional amount from the principal amount.

- The microfinance client will only repay to Islamic microfinance institution the principal amount.

- Under ZIFM, there is an existence of Tabarruq Capital Fund (TCF) or known as Donation to Capital Fund (3). The clients that are selected for ZIFM are expected to donate to this fund. They are encouraged to donate from their subsequent profits a minimum amount equivalent to $10 \%$ of their initial principal capital obtained from 
ZIFM scheme. This donation can be treated as Sadaqah for helping other clients to join the scheme.

- Islamic microfinance institution can use the fund from TCF to help other clients (4)

\section{CONCLUSION AND RECOMMENDATION}

Islamic microfinance institutional allows the establishment socio-economic justice and equitable distribution of income. These two are among the paramount goals of an Islamic economy. In Indonesia, Islamic microfinance institutions established in order to cater the need of the Muslims. One of the Islamic microfinance institutions is Shariah People Credit Bank (BPRS). Although there is a development of BPRS in Indonesia, this institution is facing so many challenges as indicated in earlier discussion.

Realizing such issues exist within the Islamic microfinance institutions, this paper sheds light on a conceptual framework of the Zero Interest Financing Model (ZIFM) for Islamic microfinance institutions particularly in Indonesia. The recent practice of ZIFM by some countries which is based on conventional point of view indicates that they are a step ahead in the right direction to help the poor. Thus, it seems that ZIFM is potential to help microfinance institution including Islamic microfinance institutions.

The existence of Tabarruq Capital Fund under the ZIFM for Islamic microfinance institutions make it differs from existing ZIFM practiced by other countries. This model is made interest free and a joint liability is formed between the Islamic microfinance institutions and the poor entrepreneur. It has important implications both at micro and macro levels. At micro level, it distributes income more fairly between the Islamic microfinance institutions and the individual borrower. At macro level it avoids creating an indebted society which also has adverse effect on the economy.

The paper contends that ZIFM can help to avoid some problems faced by Islamic microfinance institutions. Thus, as an alternative to mitigate the issues arising in Islamic microfinance institutions, Indonesian authority may take into the consideration to implement ZIFM. The model is expected to only fighting poverty, but also generating employment, bringing about capital growth, fulfilling faith satisfaction and improving skills.

\section{REFERENCES}

ABAC Malaysia (2008). Islamic Microfinance:A New Approach to Help Small Enterprises. Meeting Paper 6-C, Third Meeting 2008, The Advisory Group On APEC Financial System Capacity-Building. Hyatt Regency Hotel, Republic of China 
Ahmed H. (2003). Frontiers Of Islamic Banking: A Synthesis Of Social Role And Micro Finance. Paper was presented at the Forum on Islamic Economics and Finance, September 27-29, 2003, Amman Jordan

Ahmed, H. (2002), "Financing Microenterprises: An Analytical Study if Islamic Microfinance Institutions," Islamic Economic Studies, 9 (2), 27-64.

Chowdhury, S. (2006), Creating an Islamic Microfinance Model: the missing dimension. DinarStandard: Business Strategies for the Muslim World.

Gibbons, D. S., and Meehan, J. W. (2002). Financing Microfinance for Poverty Reduction. The Microcredit Summit Campaign. Washington

Hassan Z. (2010). Islamic Finance: The Structure-Objective Mismatch And Its Consequences. ISRA International Journal Of Islamic Finance, 2.

Hulme, David and Paul Mosley (1996), Finance against Poverty. Vols. 1 and 2. London and New York: Routledge.

IRTI (2007). Framework and Strategies for Development of Islamic Microfinance Services. Working Paper For IFSD Forum 2007 Islamic Microfinance Development: Challenges and Initiatives

Karim, N.; Tarazi, M. and Reille, X. (2008). Islamic Microfinance: An Emerging Market Niche. The Consultative Group to Assist the Poor (CGAP) Focus Note, Washington D.C.: USA.

Ledgerwood, J. 1999. Microfinance Handbook: An Institutional and Financial Perspective. Washington, DC, Banco Mundial.

Littlefield, E \& R Rosenberg (2004). Microfinance and the Poor. Finance \& Development, Vol.41, No. 2, June

Littlefield, E.; Morduch, J. \& Hashemi, S. (2003): Is microfinance An Effective Strategy To Reach The Millennium Development Goals. CGAP

Microcredit Summit (2004). State of the Microcredit Summit Campaign Report 2004. Washington DC

Muhammad (2012). Challenges of Micro Finance and Prospect of Introducing and Developing IMIM in Nigeria. Unpublished $\mathrm{PhD}$ Thesis, International Islamic University Malaysia (IIUM)

Otero, M. (1999). Bringing Development Back Into Microfinance. Latin America: ACCION International.

Rahman R.A. \& Dean F. (2013). Challenges and Solutions in Islamic Microfinance. Humanomics, Vol. 29 Iss: 4

Riwajanti N. I \& Asutay M. (2013).The Role of Islamic Microfinance Institutions in Economic Development in Indonesia: A Comparative Analytical Empirical Study on Pre and Post Financing States. Paper presented at the 9th International Conference on Islamic Economics and Finance (ICIEF), 9-11 September 2013, Istanbul, Turkey

Rosly. S. A. (2005). Critical Issues on Islamic Banking and Financial Markets, Kuala Lumpur. Malaysia: Dinamas.

Rulindo R. (2012). Impact Assessment Of Islamic Microfinance Institutions And Poverty Status With Reference Of Spirituality And Religious In Jakarta, Indonesia. Unpublished PhD Thesis, International Islamic University Malaysia (IIUM)

Saeed. M. M., Rehman. T. U., and Qasim M. (2009). Islamic Microfinance:Monitoring of Profit and Loss Sharing Loans: Case Study of Bank Islamic Pakistan. Blekinge Institute of Technology.

Seibel, D, H. (2006). Islamic Microfinance in Indonesia, Deutsche Gesellschaft für Technische Zusammenarbeit (GTZ) 
Seibel, H. D. (2008). Research Notes and Comments - Islamic Microfinance in Indonesia: The Challenge of Institutional Diversity, Regulation, and Supervision. SOJOURN: Journal of Social Issues in Southeast Asia 23(1).

Simanowitz, A \& Brody, A. (2004). Realising The Potential Of Microfinance. Insights, 51: 12

United Nations Capital Development Fund (2004). Microfinance In The Arab States Building Inclusive Financial Sectors. UNCDF, New York

Wright, Graham A. N. 2000. Microfinance Systems: Designing Quality Financial Servicesfor the Poor. Zed Books Ltd. London \& New York, and The University Press Limited, Dhaka. 